\title{
MECANISMES DE PERCEPCIÓ DE LA POESIA VISUAL: BROSSA I VILADOT, $1970^{\mathrm{I}}$
}

\author{
GLÒRIA BORDONS I DANIELA CAVALLI
}

\begin{abstract}
Joan Brossa and Guillem Viladot are indisputably the masters of Catalan visual poetry. Their books Poemes per a una oda and Poemes de la incomunicació, published in I 970, not only show the common traits of their work, but also mark a milestone in the development of this kind of poetry. This paper focuses on the reader's reception by analyzing different types of responses to these authors' books, considering: I) Their contemporary reception from comments by the authors and the Catalan press; 2) the critical examination of the formal, thematic and contextual elements of these works of poetry; and 3 ) the reception of contemporary non-expert readers, which is done by showing the results of an exploratory research study. By contrasting the results from the analysis we conclude that there are many similarities in the meaning making process undertaken by the readers considered, especially between non-expert readers and current critical examination. Readers try to make sense of the poems in rational ways, more than drawing from emotions and feelings. Nevertheless, they still show personal implication while explaining the poems.
\end{abstract}

\section{INTRODUCCIÓ}

La poesia visual és un gènere híbrid, a cavall entre les arts visuals i la literatura. Ho demostra el canal pel qual arriba als lectors: d'una banda, l'edició de llibres més o menys convencionals, encara que amb tiratges reduïts; i de l'altra, l'exhibició en galeries d'art i museus. El caràcter fronterer ha provocat que generalment se li hagi dedicat poca o nullla atenció tant des de la crítica literària com de l'artística. Tot i així, el gènere s'ha anat mantenint a través dels temps i fins i tot podríem dir que avui dia gaudeix de molt bona salut. La seva presència a la xarxa és extraordinària i l'empremta que ha deixat en el món del disseny és innegable. Però, ¿han canviat gaire coses des dels anys setanta (data de l'inici d'aquest gènere a casa nostra) en l'atenció que li dedica la crítica i en la percepció que en té el lector? Pel que fa a la crítica, continua essent minoritària. Pel que fa al possible lector-espectador, en un qüestionari realitzat l'any 2007 a estudiants de comunicació audiovisual, hi hagué una resposta prou representativa: "Penso que és un tipus de poesia força interessant, ja que deixa bastant de marge al receptor a l'hora d'interpretar el missatge, deixant marge a la subjectivitat” (Audí, Bordons, i Costa 392).

Aquesta opinió planteja un interrogant: la interpretació de la poesia visual és només subjectiva?² Aquest dubte i la cerca des de fa temps d'un model d'anàlisi per a aquest tipus de poesia ens han portat a plantejar-nos tres eixos d'indagació en dos llibres de i 970 de Joan Brossa i Guillem Viladot: la recep- 
ció de l'època, la mirada crítica sobre els poemes i la resposta d'alguns lectors no experts actuals. ${ }^{3}$ A partir d'aquí, intentarem sintetitzar quins són els principals mecanismes del procés interpretatiu que segueix el lector en la poesia visual.

\section{RECEPCIÓ DE L'ÈPOCA}

Joan Brossa i Guillem Viladot són indiscutiblement els mestres de la poesia visual catalana. Junt amb Josep Iglésias del Marquet, participaren a la primera exhibició de poesia visual ${ }^{4}$ a Catalunya, presentada a la Petite Galerie de Lleida l'any I97ı. De fet, aquesta exposició representà el fruit de tota una tasca d'introducció de l'anomenada poesia concretas al nostre país. Hi havien tingut un paper rellevant la publicació l'any i963, al número s de la Revista Cultural Brasileña, d'un article d'Ángel Crespo i Pilar Gómez sobre la situació de la poesia concreta, la vinguda d'Eugen Gomringer a Barcelona per fer una xerrada al Club 49 l'any 1967 i l'activitat desplegada per Iglésias del Marquet als diaris, ${ }^{6}$ així com un article de Guillem Viladot a la revista El Pont l'any i969, on féu una mena de programa d'aquest tipus de poesia.

Prèviament, els tres autors havien publicat llibres en els quals ja es podia veure un predomini de les lletres dins el marc de la pàgina blanca, la importància de les geometries i de la perspectiva, la repetició d'alguns mots o lletres (més, en el cas de Viladot) i l'ús d'unes determinades tipografies i, sobretot, del collage:7 el 1968, Viladot publicava Cartrons concrets i el I969 tots tres coincidien a treure obres d'aquest caràcter al carrer (Quadern de poemes ${ }^{8}$ de Brossa; $5+$ I lais concrets d'homenatge a Antoni Tàpies i Llibre del joc de les macarulles verdes de Viladot,", i POEMAS VISUALES d'Iglésias del Marquet).

Tota aquesta febre "concreta" aconduí a l'exposició de la Petite Galerie de I97i. En un petit catàlegio es reproduïa l'entrada "poesia concreta" del Gran Diccionario Enciclopédico Salvat escrita per Iglésias del Marquet i un fragment de la conferència que Francesc Vicens havia pronunciat el dia de la inauguració, a més d'una petita selecció de les obres de la mostra. L'exposició fou comentada en diferents diaris locals, però la seva importància arribà fins a Barcelona, on aparegueren cròniques a El Correo Catalán, Diario de Barcelona, Serra d'Or, La Vanguardia i a la prestigiosa revista Destino. En aquesta darrera, Daniel Giralt-Miracle deia que l'esdeveniment "es un signo evidente del grado de madurez que han conseguido dentro de esta especialidad tan poco usual e ignorada en nuestros ámbitos", destacava la novetat del llibre Poemes de la incomunicació de Guillem Viladot i dedicava gran part de l'article a ressenyar la conferència de Vicens. Ens interessa especialment el darrer fragment, que apella a la percepció del receptor i situa aquest tipus de poesia entre la literatura i les arts visuals:

En líneas generales, señala Vicens, la moderna teoría de la información y de la psicología de la recepción coinciden. Aquella ha descubierto que un mensaje contiene el máximo 
de información cuanto mayor es su ambigüedad, ésta explica que la repetición del mismo estímulo (signo o palabra) hace descender el umbral perceptivo por la disminución de las posibilidades de la sensibilidad. Por ello la poesía concreta, al utilizar las palabras como objeto, situándolas en un nuevo campo de fuerzas, donde adquiere una especial importancia su aislamiento o continuidad con otros elementos, especula con valores que son simultáneamente plásticos y literarios. (Giralt Miracle 35)

Segons Giralt-Miracle, doncs, la repetició d'un estímul (fenomen molt freqüent a la poesia concreta) disminueix les possibilitats de la sensibilitat. Sobta trobar aquest mot, però les lectures d'altres textos crítics de l'època ens mostren que la paraula era molt habitual. Ara bé, el sentit és diferent del que li donem avui. Probablement el que s'intentava dir era que el missatge esdevenia més mecànic $\mathrm{i}$ que, tot i que s'obrien nous camins significatius, el lector no podia recórrer a la via del sentiment, sinó a la de la lògica semàntica creada per la combinació de signes. Un any abans, però, M. Lluïsa Borràs havia escrit un article també a Destino sobre la poesia visual, a propòsit de l'aparició del llibre de bibliòfil Nocturn matinal fet entre Brossa i Tàpies. Borràs, d'una banda, afirmava que la crítica artística semblava més receptiva al gènere perquè estava més acostumada a la sensibilitat (i un cop més s'usava aquest mot) que no pas la crítica literària. D’una altra banda, incidia en la forma de recepció a què aquesta poesia obligava: "El poeta elige los mínimos elementos posibles para lograr un impacto que ha de captarse mediante la sensibilidad y no gracias a un raciocionio" (Borràs 39), i parlava d'un Brossa tellúric que no actuava sol (l'acompanyaven poetes joves com Carles Camps i Santi Pau) i d'un Viladot amb una obra més treballada i assequible, per la qual cosa representava una ruptura menor. A partir d'aquí feia un repàs del que havia representat la poesia concreta i dels seus propòsits, allunyats dels sentiments, de les sensacions i del pensament i més propers a l'objecte en ell mateix, i de com aquests objectius fundacionals estaven allunyats de moltes de les propostes internacionals ja dels anys setanta. Així, doncs, segons Borràs, els poetes visuals catalans (i més específicament Brossa) anaven per uns terrenys diferents de la poesia concreta justament per la forma de recepció que reclamaven, emotiva i no tan racional.

Tot seguint el debat al voltant de la interpretació d'aquests poemes, Miquel Arimany destacava el paper de l'atzar a l'hora de construir el poema i subratllava el pes que la tipografia i el dibuix tenien en la construcció del significat: "[la tipografia] ha passat d'ésser un element illustratiu d'una idea a ésser la idea, o la roda, el centre d'on com a raigs poden, per certes complementacions — sovint un mot o mots simplement, algunes o alguna lletra-, desprendre's el sentit o una gamma de sentits derivats" (202). En resum, tot i la divergència de Borràs, el que majoritàriament destacava la crítica ${ }^{\mathrm{II}}$ en aquest tipus de poesia era la capacitat de crear nous sentits. El lector, cridat "emotivament" o no, era obligat a construir "racionalment" significats. D'alguna manera, la poesia, en fer un pas cap a la imatge, s'havia convertit en més “objectiva”, com assenyalà Iglésias del Marquet (citat a Salvo I47): "La poesia comunicada per la imatge com el seu fonament substancial, el seu valor implícit, freqüentment no evoca, sinó que s'ofereix en la 
seva mateixa realitat". És clar que Iglésias del Marquet se situava molt clarament en els paràmetres de la poesia concreta (més “objectiva”), mentre que Borràs anava a altres referents internacionals que situaven aquella nova poesia més enllà del concretisme i, per tant, més enllà de la pretesa "objectivitat".

\section{Anàlisi crítica dels llibres de Viladot i Brossa}

Ens caldrà anar a l'anàlisi formal, temàtica $\mathrm{i}$ contextual dels llibres que Brossa i Viladot exposaren a la Petite Galerie per dibuixar les traces d'allò que els poetes pretenien provocar en el receptor. Segons el catàleg que es va fer per a l'ocasió, l'exposició, a més d'uns poemes determinats, aplegava unes planes impreses i originals de llibres de cadascú. Ens centrarem en els de Viladot i Brossa (Poemes de la incomunicació i Poemes per a una oda, publicats tots dos l'any 1970), per la importància que aquests dos poetes tingueren posteriorment i pel fet que el llibre Poemes humans de Josep Iglésias del Marquet ${ }^{12}$ finalment no fou publicat (Salvo 86). Tot i que amb diferències bàsiques, els dos poemaris tenen força elements comuns, com ara la presència abundant de lletres, l'absència de discurs, l'ús de fragments de la realitat i, sobretot, una instància a la participació del lector que apella molt clarament a la construcció del significat.

\section{I. Poemes de la incomunicació}

El poemari de Viladot porta un títol ben significatiu. A més, va precedit de quatre citacions allusives al tema. La primera, d'Iglésias del Marquet, afirma que el llenguatge descansa sobre els cinc pilars fonètics de les vocals i diu textualment: "Degudament matisades, són la clau de la comunicació verbal, encara que entre la nostra parla i la del proïsme sempre hi trobarem un mur" ${ }^{13}$ La segona, presentada com a "text d'altri adient", afirma que "la comunicación se verifica a modo de esferas tangentes, que contacta una respecto de la otra por la periferia del Yo de cada cual". La tercera citació és un fragment del llibre La incomunicación de Carlos Castilla del Pino i se centra en la fallàcia que ens ha causat la racionalització, ja que tots acabem per creure'ns sincers i dubtem dels altres. Finalment, el pròleg de Joaquim Marco a Antologia de la Poesia Catalana del Segle d'Or posa el punt final a la introducció. El que en aquest cas s'hi destaca és que "la poesia, molt més que cap altre gènere, permet una primera lectura en què la imaginació del lector pot suplir allò que no entén". Amb molts anys de separació és el mateix que un crític actual de la poètica cognitiva ha destacat: "In general, the less prototypical the style, the more potentially open the text is for readerly intervention and activity in interpretation. Writerly texts, which present prototypical expectations at every level, are more closed to readerly work" (Stockwell 36 ).

Mitjançant aquestes citacions, Viladot situa el lector en un doble terreny. D'una banda, els paratextos inicials ens porten cap a un significat clar: la inco- 
municació i les dificultats de relació entre el jo i els altres; de l'altra, però, a través de la darrera citació, el receptor està avisat que li caldrà un esforç d'imaginació per acabar d'entendre el que trobarà en les pàgines següents.

Un cop entrem en el llibre, el que trobem són poemes construïts bàsicament a partir de les vocals $i$ una gran quantitat de barres verticals gruixudes que ens suggereixen petits murs. Aquest element s'ha presentat simbòlicament com la "impossibilitat d'anar fora" $\mathrm{i}$ alhora com a "espai protector" de l'individu (Cirlot 3 I6). Des de la psicologia és, doncs, fàcil induir-ne un significat d'incomunicació. Alguns dels poemes de Viladot són molt propers a un poema "corpori" que Brossa va realitzar l'any i994 a l'espai de davant del Servei de Telecomunicacions d'Andorra. El títol, "Capvespre i/o Incomunicació" (fig. 2), atorga un significat ben clar al mur que parteix una taula al mig de la plaça andorrana.

\section{i|..|}

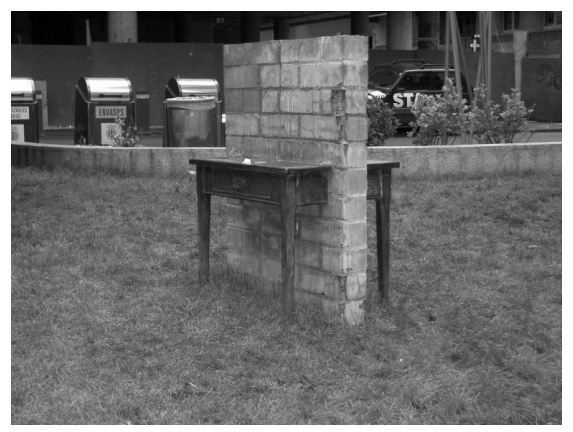

Fig. I

Fig. 2

L'acompanyament dels punts suspensius com a possible "espai exterior" (fig. I) és un altre dels signes icònics identificables en Viladot. D’altra banda, un dels pocs mots presents en el llibre és “jo", amb la qual cosa la construcció del significat indicat en les citacions inicials es confirma: el jo incapaç de sortir d'ell mateix, el jo aillat en la seva bombolla o el jo narcisista que només pot veure el seu ego són possibles lectures de poemes centrats en el "jo" (figures 3, 4 i 5 ):

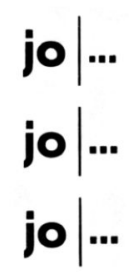

Fig. 3

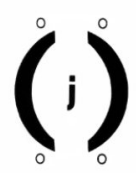

Fig. 4

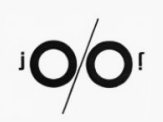

Fig. 5 
Per crear aquests significats i que les lletres puguin funcionar com a icones, Viladot s'acompanya de la tipografia, de l'ús alternat de majúscules i minúscules, de traços més o menys gruixuts, així com de la repetició. Aquest és un recurs bàsic i molt utilitzat en la poesia concreta. Però no és cap novetat, ja que l'anàfora, com s'ha destacat a bastament en la teoria poètica, seria un dels trets distintius del gènere. En aquest cas, però, els elements recurrents són mínims i asintàctics. L'ús de vocals i les diferents maneres de repetir-les acosta aquests poemes a la música, ${ }^{\mathrm{I} 4}$ tot dibuixant diferents "variacions" dins del conjunt. No és d'estranyar, doncs, que Brossa, que utilitzava també aquesta tècnica, anomenés alguns d'aquests poemaris "suites" de poesia visual. D'altra banda, aquesta recursivitat "visual” pot accentuar l'efecte cognitiu sobre la memòria a curt termini assenyalat per Reuven Tsur a propòsit de la mètrica (Tsur 73).

Però no totes les composicions de Poemes de la incomunicació reclamen un significat. N'hi ha que, a més de les lletres, recorren a la creació òptica de moviments concèntrics. En el primer cas, Viladot, com a persona interessada en la psicologia i els fenòmens de percepció, ${ }^{15}$ inclou elements "òptics" d'una manera clara en dos dels poemes. En el primer (fig. 6), se'ns presenta un cercle (recordem que, segons un dels textos inicials, la comunicació està formada per esferes tangents) farcit d'altres cercles concèntrics, que aboquen a un espai buit oval. Un traç gruixut encercla l'ull central i dibuixa un possible itinerari d'inici al moviment. Fora de la circumferència, uns signes d'admiració reforcen la sorpresa i l'enigma. En el segon (fig. 7), s'enfoca una diana en el centre de la qual hi ha un "No", acompanyat de signes d'admiració. Tant en un cas com en l'altre sembla que Viladot aprofita recursos òptics també utilitzats per l'art pop per cridar l'atenció del lector cap a elements que el portin cap a la reflexió sobre un mateix i sobre la comunicació amb els altres. Com ha dit Jaume Pont: "el concepte de simetria, central en la teoria de la psicoanàlisi, ens mena a la imatge del mirall, és a dir a la necessitat de trobar-nos reflectits en una sèrie d'objectes que ens puguin retornar la nostra imatge profunda" (I 2 I-I 22). Una possible lectura del primer poema seria el qüestionament d'una perpètua mirada cap a l'interior de la persona. I la significació del segon podria anar cap a la revolta interior. Però per atorgar aquests significats el lector ha hagut de recórrer al seu saber cognitiu i pràctic més que no pas a una reflexió formal sobre allò que veu (Audí I 85 ). L'experiència literària probablement no li ha servit de gaire per fer aquesta construcció. D'altra banda, no és segur que tots els lectors puguin arribar a les mateixes conclusions, malgrat que la disposició gràfica pugui seguir alguns dels principis de percepció visual de la Gestalt, com ara el de tancament, i que l'existència d'un centre clar aboqui la mirada cap a un punt, segons la psicologia aplicada a la interpretació de l'art (Arnheim 56-57).

Un mínim nombre de poemes incorpora documents reals del context, com també veurem que fa Brossa de manera més freqüent. A Poemes de la incomunicació són dos els casos, dels quals destaca el fragment de la guia telefònica amb una "O" collocada a sobre de "Religiosas Misioneras Cordimarianas" i 


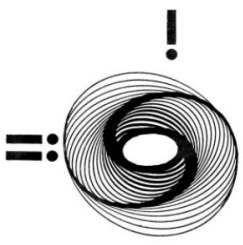

Fig. 6

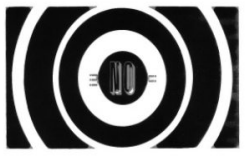

Fig. 7

"Restaurante Bernat" (fig. I I). ${ }^{16}$ L'estranyesa d'aquests fragments de realitat incorporats a la pàgina converteix aquest poema gairebé en allò que Christophe Hanna ha anomenat "objectes literaris no identificats". Tot i que el crític francès es refereix a obres aparegudes a partir de 1990, el procés lector que descriu seria aplicable també a aquest poema:

Les modes de lecture qu'ils réclament paraissent non seulement répondre à une autre conception du littéraire, mais même jouer tactiquement de leur ambiguité générique, comme si leur furtivité, une intentionnelle manipulation des apparences, conjuguées à d'évidentes facultés d'adaptation aux divers contextes dans lesquels ils circulent, étaient partie prenante de leur mode d'être. (Hanna I)

Efectivament, el procés d'interpretació ha de passar tant per una reconstrucció del context sociohistòric com per una construcció de significats totalment lliure que relacioni els diferents elements presents a la pàgina. La tècnica usada, el collage, acostuma a incitar aquest tipus de lectura tant en els poemes més contextuals com en d'altres en què les lletres apareixen sobre elements ben diferents. En conseqüència, cada lector pot establir un tipus de relació diferent, tant dins del poema com entre els diversos poemes d'una seqüència. En aquest sentit, és força simptomàtic que els quatre poemes finals siguin els de més lliure interpretació.

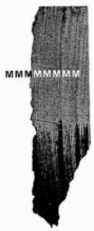

Fig. 8

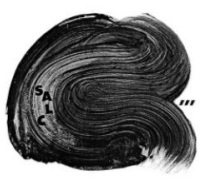

Fig. 9

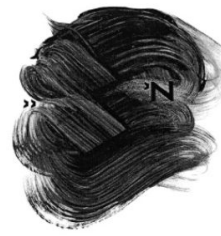

Fig. Io

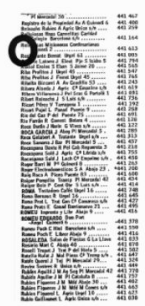

Fig. I I 
El procés s'adequa totalment a la descripció que Umberto Eco havia fet justament uns anys abans a propòsit de Mallarmé i que posteriorment han desenvolupat altres autors en relació amb aquelles obres que, per "obertes”, suggereixen "emocions" diferents, segons qui siguin els individus que s'hi apropin:

Es preciso evitar que un sentido único se imponga de golpe: el espacio blanco en torno a la palabra, el juego tipográfico, la composición espacial del texto poético, contribuyen a dar un halo de indefinido al término, a preñarlo de mil sugerencias diversas. ... La obra que "sugiere" se realiza siempre cargada de las aportaciones emotivas e imaginativas del intérprete. (Eco 70)

\subsection{Poemes per a una oda}

En el llibre que l'any i97 I Brossa exhibia al costat del de Viladot, es demanaven al receptor els mateixos processos d'interpretació? D'una banda, veiem que alguns dels recursos utilitzats són els mateixos, com ara les lletres i els documents reals, però, de l'altra, la intenció és diferent. I també en molts casos els poemes imposen una lectura totalment oberta.

Pel que fa a les lletres, com en Viladot, abunden les vocals (especialment la A), però, a diferència del poeta agramuntí, n'hi ha poques per pàgina i no sempre estan repetides. De la combinació amb consonants, de vegades sorgeixen objectes inesperats (fig. I 2 ) o paraules en què el joc amb les diferents mesures $\mathrm{o}$ tipografies pot induir el lector a una reflexió sobre el significat dels mots (figures I 3 i I 4: “or" i "nan”). De vegades són els títols els que tenen una funció "metalingüística" i alhora "metafơrica", com en el poema "Viatge" (fig. I 5 ).

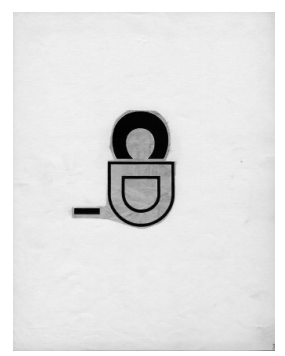

Fig. I 2

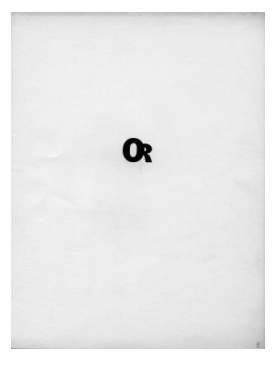

Fig. I 3

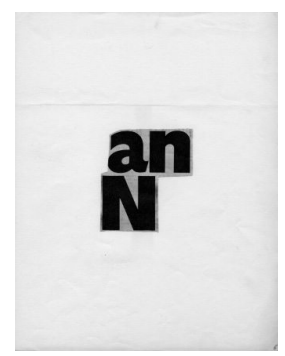

Fig. I 4

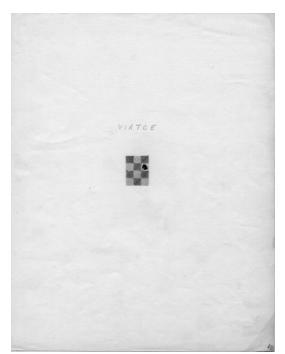

Fig. Is

Aquests títols, com és habitual en Brossa quan en posa, donen pistes per a la interpretació, ja que serveixen per activar esquemes mentals i emmarcar expectatives ja sigui perquè l'etiqueta vol fer pensar sobre el significat de les coses, com és el cas de "Mirall" (el mot té com a reflex una altra paraula, "Viatge") o "Errata"; ja sigui perquè remet a una analogia que acondueix el receptor cap a 
reflexions que el porten més enllà (com ara el poema "Saturn"). El poeta havia deixat clares les seves intencions en més d'una ocasió: l'any 1965, a la presentació del llibre editat en collaboració amb Antoni Tàpies, havia dit: "A les pàgines de Novella la invenció formal i la realitat quotidiana donen pas a una mena de llenguatge integrador - òptic i profund, anònim i personal alhora- que obliga el lector a explorar la seva forma de consciència i a veure-hi més enllà dels seus ulls" (Brossa, Vivàrium 65).

Per reflexionar sobre les coses, no sempre és necessari el llenguatge, com es demostra en el poema de la figura i 6 (justament allò que el defineix és el que no té). Pel que fa als documents reals, Poemes per a una oda en conté més que el llibre de Viladot: la reproducció de la portada del llibre Poesia rasa del mateix Brossa, una entrada de teatre i un full de calendari del mes de juliol de 1936, en el llibre publicat, $\mathrm{i}$ un tercer document, una notícia, en el manuscrit original. ${ }^{17}$ La intenció dels dos poemes més polítics es reflecteix clarament en el títol: "Record” (fig. I7) i “Oda” (fig. I 8). És clar que la significació aquí sorgeix del coneixement del context $\mathrm{i}$ que, sense aquest, és difícil entendre en profunditat el poema. Tanmateix la lectura de la notícia d'“Oda" (la repressió - amb mortsd'una manifestació d'obrers per part de la policia, narrada com si haguessin estat els treballadors els atacants) pot despertar en el lector la ira i la ràbia que l'escriptor pretenia sense la necessitat que conegui la situació social dels anys setanta a Espanya. També el poema amb la portada de Poesia rasa és totalment contextual, ja que si el lector no sap que aquest és un volum publicat per Brossa l'any 1970 no podrà descobrir ni la ironia ni l'autoreferència que l'autor realitza en el poemari (amb el consegüent joc proporcionat pel títol, ja que Poesia rasa també es pot referir als poemes de Poemes per a una oda).

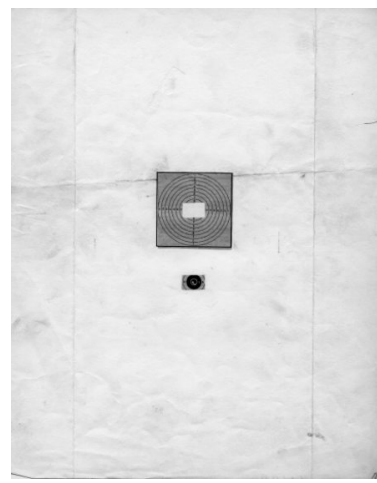

Fig. I 6

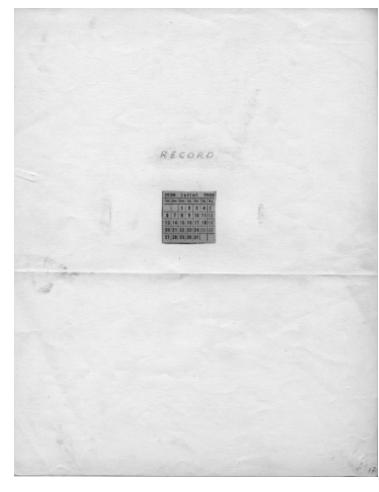

Fig. I7

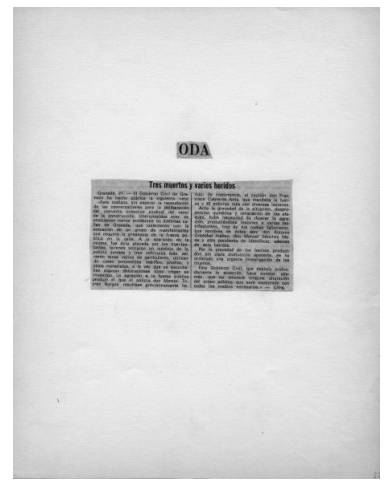

Fig. I 8

Com es pot veure en les imatges (tant les del manuscrit com les del poema editat), en Brossa les traces del collage són molt clares. D’aquesta manera, la 
matèria surt gairebé de la pàgina per ajudar a situar el receptor en el context en què foren produïts els poemes. A diferència de Viladot, hi ha pàgines foradades o retallades (el camí entre la A i la Z, fig. I9) i, fins i tot, la mitja entrada de teatre és real, de manera que podem agafar-la i treure-la del llibre. El lector és així convidat a l'acció i a no romandre passiu. Fins i tot el mateix objecte que té entre les mans (el llibre) és contemplat com a matèria, una visió propiciada per la inclusió d'un centímetre retallat i enganxat al límit de la pàgina (fig. 20). El llibre es converteix així en un hipertext i l'espai de lectura esdevé el teatre en

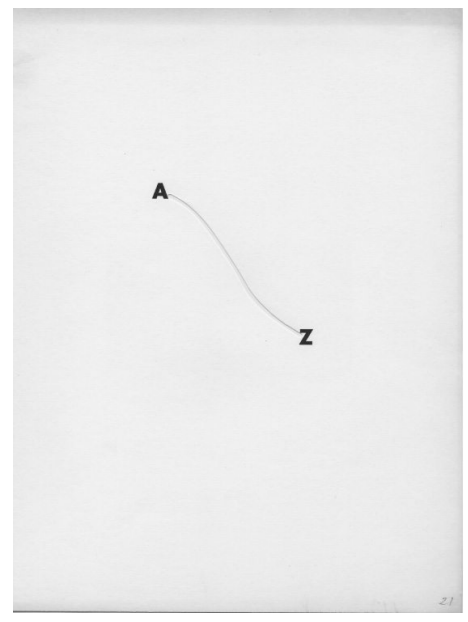

Fig. I9

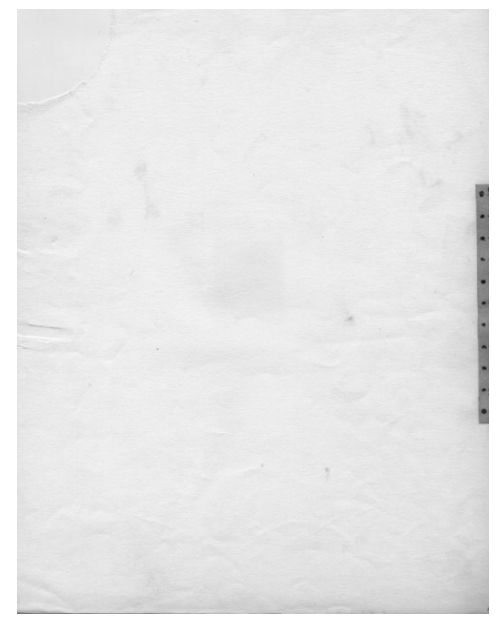

Fig. 20

què el lector és el protagonista.

La idea és la posada en pràctica de la concepció que el mateix Brossa havia expressat en el poema "Preludi” d'El saltamartí (escrit el 1963 i publicat el I969): "Aquests versos, com / una partitura, no són més / que un conjunt de signes per a / desxifrar. El lector del poema / és un executant". Alhora cal tenir en compte que Brossa era un home de teatre ${ }^{18} \mathrm{i}$ que des de 1946 escrivia "accions espectacle" o postteatre, unes peces escèniques en què l'espectador es convertia en moltes ocasions en un personatge més.

Finalment, caldria dir que, igual que en Viladot, alguns poemes són totalment oberts i enigmàtics, amb la qual cosa les lectures poden ser ben diverses.

En resum, com hem pogut constatar, els poemes visuals de Brossa i Viladot, ja sigui amb intencions significatives clares o bé amb propostes totalment obertes, solliciten una activitat interpretativa del lector molt intensa i conscient, a diferència de la que reclama la poesia no experimental, en què el procés de donar sentit és més inconscient. Podríem considerar-los uns "documents 
poètics", per dir-ho amb paraules de Frank Leibovici, o "dispositius" que el lector ha d'activar i interpretar:

Par nature, tout dispositif est producteur d'une signifiance potentielle qu'un lecteur doit actualiser. Non seulement le dispositif présente un système de lecture relâché parce que discontinu, mais il demande un surcroît d'activité de lecture (il réclame d'activer simultanément plusieurs codes de lecture et de les relier entre eux, c'est-à-dire d'être sensible à leur interférence). (Hanna 93)

\section{LA MIRADA DEL LECTOR NO EXPERT}

Tots aquests processos d'inferències de significat que hem reflectit més amunt, es donen també en els lectors no experts dels nostres dies? Per conèixer-ho hem dissenyat una petita recerca que ha tingut un caràcter exploratori i s'ha realitzat amb una metodologia qualitativa.

Els lectors escollits han estat un grup de trenta-quatre estudiants de primer del grau de Mestre d'Educació Primària d'una mitjana d'edat de vint anys. ${ }^{19}$ En primer lloc se'ls mostraren en pantalla de manera seguida i ràpida tots els poemes dels dos llibres de Viladot i Brossa, i se'ls proporcionà la mínima informació contextual (any de redacció i publicació, títol dels poemaris i situació política, social i cultural). A continuació se'ls indicà de respondre dues preguntes tancades: si havien vist poemes semblants anteriorment i si coneixien els autors. ${ }^{20}$ Tot seguit se'ls presentà una selecció de deu poemes d'un llibre i de l'altre, ${ }^{21}$ amb un temps breu (dos minuts) per escriure unes notes. Les instruccions foren: "Per a cadascun dels poemes que veuràs, anota breument en què et fa pensar, què et suggereix, quin sentit li dónes, etc.”. Vàrem usar expressament aquestes paraules i no d'altres per tal de facilitar que els alumnes expressessin els seus pensaments i reaccions personals sense que sentissin la necessitat d'explicar el poema a algú, sinó més aviat d'explicar-se'l a ells mateixos. Miall i Bruner ja havien indicat que donem sentit a la realitat $\mathrm{i}$ a allò que hi trobem mitjançant la construcció de narratives, la lògica de les quals és més aviat interna, és a dir, que existeix en el mateix llenguatge. Esperàvem, doncs, que els alumnes traguessin a la llum el seu sentir personal —i també social.

Finalment, els preguntàrem si portarien a una classe de primària algun d'aquells poemes i per què. Sorprenentment, vint alumnes digueren que sí.

Hem analitzat interpretativament les dades (les respostes per escrit dels alumnes) amb una aproximació fenomenològica, basada en l'observació del discurs generat pels estudiants, tot tenint en compte les aportacions tècniques de la psicologia (Bruner; Tannen), de la lingüística (Lakoff i Johnson) i de la poètica (Stockwell; Oatley) cognitives, així com les d'alguns estudis empírics de la literatura (Kuiken, Miall i Sikora; Miall).

Malgrat la pretensió qualitativa d'aquest estudi, la metodologia emprada no ha permès que ens endinséssim en profunditat en el món dels lectors per tal 
d'entendre'l a partir de la subjectivitat i del context de cadascú. ${ }^{22}$ Tot i això, conscients de la limitació de les nostres dades, hem intentat fer una anàlisi que no restringeixi la complexitat del fenomen observat. És des d'aquesta constatació que formulem explicacions i interpretacions.

Un cop examinades les respostes $i$ atesa la complexitat de l'anàlisi, ens hem centrat en tres poemes de cada autor, precisament els que havien donat més joc entre els lectors. Pel que fa a les respostes, hem de començar referint-nos a una minoria que no dóna cap sentit als poemes. És possible que alguns alumnes, tot $\mathrm{i}$ haver construit algun significat, no volguessin donar una resposta, ja que tenim l'evidència que hi hagué qui es tancà a fer-ho pel fet de pensar que no l'entenia. Efectivament, a la pregunta final del qüestionari, un terç dels enquestats respongué que no portaria aquest tipus de poesia a una classe de primària, tot argumentant que el problema radica en el fet que "no s'entén":

No, perquè jo que sóc més gran no els he entès, els petits no ho faran. Però tot i així, en portaria alguns de mostra perquè deixessin fluir la imaginació. / No ho sé, potser si en treballéssim la capacitat imaginativa des de petits jo no m'hauria trobat avui en la situació de no tenir ni idea d'interpretar què volen transmetre aquests autors. / No, perquè no em sembla una poesia que es pugui entendre. ${ }^{23}$

Malgrat aquesta resposta negativa, ells mateixos reconegueren que hi havia una ruta alternativa per donar sentit als poemes: la imaginació. Efectivament, parlar de què els suggeria o en què els feia pensar el poema no se situaria gaire lluny del que ells entenien per imaginació.

Quant a la reacció dels alumnes que van donar un sentit als poemes, o en van imaginar un, sorprèn la coincidència en les interpretacions. Tot $i$ que hi ha alguna resposta aillada, la manera de donar significat es repeteix, per bé que amb matisos. Per exemple, és força comú que s'activi un marc d'interpretació derivat del títol del poema, com ara el cas de "Record" de Brossa o del poema número $\mathrm{I}^{24}$ de Viladot, situat immediatament després del títol del poemari, $P_{O}-$ emes de la incomunicació. També és freqüent que els lectors projectin la pròpia realitat humana a elements no humans, que poden ser signes (punts, línies... en els poemes de Viladot) o objectes (un regle, un tros de paper retallat, una diana... en els de Brossa).

D'altra banda, les respostes també tendeixen a coincidir a l'hora de mostrar una major o menor implicació personal, tant si és mitjançant l'expressió de sentiments i de judicis de valor com a través d'una participació sensorial. En tots dos casos veiem que això s'esdevé principalment en el significat de les lletres: en el poema número 3 , les lletres s'identifiquen amb el pronom “jo", $i$ en el poema número 8, les lletres "MMM" són preses per una onomatopeia que és interpretada de diverses formes.

Finalment, un altre fenomen comú és el de la interpretació a partir de la percepció d'una similitud visual amb una realitat externa. Tanmateix la recurrència d'aquest cas és menor i majoritàriament centrada en el poema número 8. 


\section{I. Poemes per a una oda}

En el cas dels poemes I 6 i 20, la majoria dels alumnes hi trobà el sentit tot relacionant els elements del poema amb objectes copsats de forma metafòrica. ${ }^{25}$ En conseqüència, les respostes presenten interpretacions d'aquests objectes-metàfora a partir de la pròpia realitat humana. Els valors associats a aquests objectes són projectats a una realitat menys concreta de la qual ells, l'autor o la societat formen part. ${ }^{26}$

D'una banda, veiem que en el poema 20 hi ha alumnes que perceben una contradicció entre els elements (el centímetre o regle i el tros de paper retallat) i la sintetitzen (“Trencar la norma. / Mesurar la ruptura”), mentre que d'altres l'emfasitzen tot marcant-ne l'antítesi o paradoxa: "Precisió i a la vegada desastre, imperfecció. / Hem trencat un tros de paper de manera irregular, tot i que tinguem un regle a l'altre extrem. / Em fa pensar que vol mesurar alguna cosa, però que aquesta està trencada". La síntesi també es pot presentar per enunciació d'una sentència o màxima: "No tot es pot mesurar. / Mesurar les vegades que ens hem equivocat o ens equivocarem al llarg de la vida i les conseqüències”. Hi ha alumnes que no hi perceben, o bé s'estimen més no mencionar-ho, cap contradicció $i$ es refereixen als valors intrínsecs del centímetre o regle: "Mesura, exactitud. / Precisió, rigidesa". Tanmateix la condició abstracta i succinta de les respostes en dificulta l'anàlisi, ja que no ens aclareix del tot si es produeix una autèntica projecció metafòrica dels valors associats a aquests objectes.

D’altra banda, en el poema i 6 el fenomen és encara més evident, ja que la projecció metafòrica s'observa en tres quartes parts de les respostes. De la possible càrrega metafòrica de l'objecte "diana", una gran majoria construeix interpretacions entorn dels conceptes de "centre" o "objectiu". Hem classificat aquestes respostes segons el grau d'implicació del lector, ${ }^{27}$ perquè aquest és un altre element fonamental en la recepció dels poemes. Hi ha casos d'implicació directa ("No trobo el centre; descentrat. / Pensar més enllà del que pot ser correcte"), tot i que sovint no s'expressi en primera persona del singular ("Em suggereix que canviem molt ràpid d'objectiu. / El centre de les coses es troba allà on tu vulguis colllocar-lo"). I d'altres en què la implicació personal s'observa en l'aprenentatge de la vida ${ }^{28}$ propi del jovent: "Pot ser una metàfora: no sempre cal encertar la diana. / La vida no té solament un objectiu, sinó que en té molts, de més i menys importància”. Només en un cas es manifesta una reacció emocional que comporta implicació en una dimensió clarament afectiva: "El fet de tenir el centre de la diana foradat em transmet un sentiment de buidor".

La desvinculació del jo lector apareix molt poc, i encara en interpretacions gairebé literals o per a les quals no tenim prou elements d'avaluació. "Inexactitud. / El centre es veu extrapolat, es veu desplaçat fora del context".

En canvi, si ens fixem en el poema 20, el grau d'implicació del jo lector és menys evident. En general, les interpretacions són més impersonals i no tan sols a nivell discursiu, sinó també pel que fa al contingut. Tot i això, hi ha un 
grup de respostes que fan referència al jo lector com a protagonista que interpreta, sent, recorda, etc.: "Regle, mesura. Em recorda o em fa pensar en quin nivell tinc en llengua catalana. / Em fa pensar en l'escola, en els paperets que trencàvem per escriure'ns 'notetes'”. Hi ha dos casos en què es manifesta una relació emocional amb el poema: "Per més que tot estigui calculat i mesurat, les coses es trenquen. Em desperta impotència. / La rectitud, ser una persona recta, li crea angoixa i per això trenca un tros de paper. / L'estar estripat el paper m'inspira ira”.

Pel que fa al poema i7 (el full de calendari del juliol de i936), és evident que el títol i la imatge del calendari activen un marc o esquema interpretatiu ${ }^{29}$ específic. Podríem dir que l'expectativa que es genera és la d'“una data que es recorda i singularitza, perquè és important per algun motiu i per a algú", amb diverses variants. Hi ha respostes que citen el "record" com a fet important, però algunes no mencionen per a qui ho és ("Algun fet important davant el mes de juliol, alguna cosa a recordar”). D’altres, en canvi, en destaquen la repercussió per a la societat ("Record d'un any significatiu per a molta gent"), per a l'autor ("Simplement li devia passar alguna cosa que vol recordar sempre aquell juliol") o per al mateix lector ("En aquest poema em vénen al cap records meus viscuts aquell mes"). En aquests casos el poema es personalitza i, per tant, es desvincula del context, ja que fa abstracció de l'any indicat en el full de calendari, data en què no havia nascut cap dels alumnes que participaren en aquest estudi.

La implicació personal no tan sols es fa evident en els exemples de personalització del poema, sinó també en la resposta emocional que genera en alguns alumnes. Hi ha un lector que fins i tot s'hi implica tot parlant d'altres: "Em suggereix nostàlgia. Com quan esperes que arribi un dia, i quan passa, trigues poc en oblidar-ho. / Aquest poema m'agrada. Suposo que qui el va composar tenia un bon record d'aquell mes o d'algun dia d'aquest mes". En la mateixa línia, s'observa que el poema és útil per construir o expressar una reflexió: "Mitjançant un calendari antic, posa per títol la paraula 'record' perquè totes les coses del passat, per insignificants que semblin, formen part de la història".

Finalment, hi ha les respostes en les quals el "record" es relaciona directament amb la Guerra Civil espanyola: "Guerra civil espanyola. El que va passar en aquella època. Record dolent, suposo. / Un dia important durant la guerra civil, potser el dia que va començar". És evident que s'activa el mateix marc interpretatiu dels exemples anteriors, però el coneixement del context ajuda a donar-hi un sentit específic i, per la naturalesa de l'esdeveniment evocat, a provocar una reacció emocional: "Guerra civil espanyola, tristor, angoixa, temor, inici d'un llarg període d'obscuritat". Cal dir que només set de les trenta-quatre respostes al qüestionari (un 20,5 per cent!) van aconseguir relacionar el poema amb l'inici de la Guerra Civil espanyola, resultat que no deixa de sobtar-nos, atesa la rellevància de l'esdeveniment. 


\subsection{Poemes de la incomunicació}

Tal com hem esmentat, en la lectura del poema i hem observat que s'activa un marc o esquema d'interpretació derivat directament del títol del poemari. El text és contemplat d'acord amb les expectatives generades entorn de la temàtica de la incomunicació. També per això s'observa la projecció de les característiques de la realitat personal i social dels lectors vers els elements del poema, en aquest cas punts, línies i, de vegades, lletres. Per bé que, com era previsible, les interpretacions metafòriques d'aquests signes emfasitzin diversos aspectes de la incomunicació, hi predomina l'opinió negativa. De vegades les línies són vistes com a barreres i es remarca la separació que imposen entre persones: "Una barrera que no permet que es trobin. / Falta de comunicació degut a barreres externes. Em fa pensar en dues persones que per culpa d'unes barreres, uns prejudicis, no es poden comunicar". En altres casos es destaca la igualtat de les persones que són separades: "Els ciutadans creen parets que ens impossibiliten de conèixer algú igual. / Interacció de dos subjectes iguals, però amb la separació de murs", $\mathrm{i}$ fins i tot en un cas el poema és interpretat com a formulació d'una sentència moral: "Em fa pensar en la igualtat. Tots som iguals i ens hem de respectar els uns als altres". Només hi ha una resposta que, partint de les possibilitats ofertes per la temàtica de la igualtat, sembla que n'extreu una visió menys negativa: "Barreres entre dos iguals que s'intenten diferenciar".

La incomunicació també és observada explícitament com a distància entre dues persones, tot i que en la majoria dels casos no s'ofereixen explicacions de les possibles causes: "No poder parlar dos individus aillats. No comunicació. / Em recorda la distància o la possible distància entre dues persones o entre grups d'iguals". A propòsit d'aquesta incomunicació, també crida l'atenció el fet que gairebé tots els alumnes mantinguin una distància interpretativa i no s'hi sentin implicats a nivell personal. Fins allà on les dades obtingudes ens han permès d'observar, gairebé ningú assumeix com a pròpia no ja la incomunicació, sinó la separació entre persones. De les respostes susceptibles de ser incloses dins aquest marc interpretatiu, només en una es pot copsar l'expressió directa d'una emoció o d'un sentiment ("M'inspira alguna cosa tancada, sentiment de claustrofòbia envoltat entre dues parets”), cosa que comportaria un determinat grau d'implicació.

Sobre aquest poema, a més, s'ofereixen algunes interpretacions potser més literals, en les quals la focalització es trasllada dels elements més evidents al fons que els conté (Stockwell i 5-20). Per exemple, hi ha qui veu l'espai entre signes com un temps, una suspensió, un no-res: "Espai de temps entre dos punts. / Fa com una relació entre les 'i' i els punts suspensius, com si al mig s'afegís alguna cosa: i... suspens, intriga".

Pel que fa al poema 3 , al contrari del que s'observa a l'ı, sembla que gairebé tots els lectors es captinguin en la interpretació de manera més personal. Les lletres hi són llegides com si es tractessin del pronom “jo”. A partir d'això, hom podria pensar que la repetició del pronom no solament actua com a contingut, 
sinó que és una apelllació al mateix lector. Com que no hi ha més contingut, la dixi implica directament el lector.

Aquesta implicació s’observa en diversos aspectes. En primer lloc, com una mirada crítica que es personalitza en major o menor grau. Un ampli nombre de respostes interpreta els elements del poema com a metàfores de l'egocentrisme: "L'única paraula que compta és la pròpia. / Egocentrisme; només penses en tu mateix. / Egocentrisme; jo, i els altres no m’interessen”. Són ben pocs els casos en què l'egocentrisme podria ser vist com a una problemàtica més aviat aliena al lector: "Em suggereix una persona que només pensa en ell mateix, és a dir, egocèntric. / Primer jo, després jo i sempre jo. Seria la descripció d'algú egocèntric i egoista”.

En segon lloc, hi ha alguns lectors, pocs, que s'impliquen des d'un marc interpretatiu en el qual el pronom “jo” no representa l'egocentrisme, sinó més aviat l'aillament o la soledat. A més, en aquests casos la resposta comporta sentiments o emocions: "La soledat de les meves paraules que no troben respostes. / Impotència”. De vegades, les respostes denoten que la soledat està relacionada amb la incomunicació: "La incomunicació amb un mateix. / La impossibilitat de comunicar alguna cosa personal. P. ex., Jo... i no poder dir res. / Tothom diu ‘jo’ i entre el soroll només se sent això”.

També en aquest poema predominen les lectures que emfasitzen els aspectes negatius, potser a causa de les expectatives que ja ofereix el títol del poemari. Tanmateix hi ha algunes respostes que es plantegen en termes més neutrals ("Diferents persones i diferents punts de vista / Tres grups d'iguals parallelament treballant sense cap diferència $i$ /o conseqüència”) i fins $i$ tot n'hi ha que veuen el “jo” des d'una perspectiva totalment positiva: “La importància de la pròpia estimació”.

Per acabar, volem destacar una resposta aillada que fa una descripció força literal dels elements, però que implícitament podria estar reconeixent una intenció lúdica per part de l'autor o de la veu poètica: "Juga amb el pronom i la vocal “o” en negreta”.

Si passem al poema 8 , les dades suggereixen que gairebé la meitat dels lectors hi construeix un sentit a partir de les lletres "MMM", les quals en aquest cas són vistes com a representacions del fonema “ $\mathrm{m}$ ”. La seva repetició constituiria una onomatopeia la interpretació de la qual va variant segons els lectors, per bé que amb força coincidències.

En primer lloc, és interpretada com l'expressió d'un dubte o d'un pensament que, per qualsevol motiu, no és clar: "Titubeig quan no se sap què dir, difuminació de les idees. / Pensaments o somnis. / Pensaments contradictoris. / Els nostres dubtes".

En segon lloc, l'onomatopeia s'interpretaria com a expressió d'emoció, de sentiment, de sensació física, possiblement a causa d'alguna similitud sonora: "Plaers efímers. / Alguna t'agrada, et sedueix. / Em suggereix el plaer d'una dutxa d'aigua freda en un dia calorós. / Desig. / Em recorda a una pinzellada de xocolata negra desfeta perquè apareixen les lletres 'mmm'; si no pensaria que 
seria una pinzellada de pintura". Algunes respostes també suggereixen la identificació d'alguna semblança visual.

És remarcable el poder de la implicació sensorial, que pot estendre's a més d'un dels sentits (oïda, vista, gust i tacte, com hem vist en els exemples) i que pot arribar a imposar-se per damunt del marc interpretatiu de la incomunicació. Podem pensar amb Lakoff i Johnson que l'experiència física del món - l'embodied experience - també és la base del nostre pensament i del nostre llenguatge metafòrics. Tanmateix no sabem per què precisament aquest poema - i cap dels altres - motiva una implicació en aquesta línia. Seria interessant reprendre aquesta qüestió en estudis posteriors, en els quals es pugui accedir a explicacions per part dels lectors, o generar-les.

D'altra banda, sembla que la interpretació més comuna d'aquest poema es produeix mitjançant analogies visuals (color, forma...): "Contrast entre la nit i el dia. / Em fa pensar en una cascada. Això ho veig molt clarament. / Sembla que la tinta d'un bolígraf s'hagués escampat. / Em recorda un tros de pantalon texà tacat i trencat; és a dir, com un record que mai vols oblidar i guardes en la teva memòria”.

També en interpretacions que atorguen un valor de "pensament" a l'onomatopeia "MMM" es consideren determinats aspectes visuals que estableixen similituds amb objectes o fenòmens: "La vida vista en blanc o negre, sempre reflexionant. / La 'M' sembla que estigui pensant i tot l'altre sembla una cascada d'aigua de pensaments".

Les mencions del concepte de "diferència" que són presents en diverses respostes a aquest poema, també les hem considerat interpretacions basades en aspectes visuals; en aquest cas, en el contrast de colors ("Diferenciació i discriminació. / Em fa pensar en la diversitat"). En unes poques ocasions el concepte es relaciona amb la temàtica de la comunicació, just el contrari del títol del poemari: "Diferents maneres de comunicar-se. / Les mateixes paraules, segons qui les utilitza, poden ser contràries. Qui les manipula en canvia el sentit".

\section{Conclusions}

Si reprenem la nostra pregunta inicial després del breu recorregut analític que hem traçat, podríem respondre que la interpretació de la poesia visual és, en general, poc subjectiva, ja que tendeix a la construcció d'un significat en termes racionals o bé a la racionalització de l'emoció. Tot i que Maria Lluïsa Borràs, a l'època, havia parlat d'emoció, la resposta dels nostres lectors no experts ha estat molt "racional", ja que, amb diferents estratègies, tots han intentat donar un sentit lògic als poemes. És cert que les instruccions que havien rebut influïren en la seva aproximació. Tanmateix les respostes a les preguntes més globals del qüestionari demostren que en la ment dels alumnes la tendència més habitual davant d'un poema és la d'“explicar-lo".

D’altra banda, la poesia visual en general és abstracta i tenen raó els crítics 
(Francesc Vicens, Daniel Giralt-Miracle) que la resposta del lector resulta més objectiva que la d'un poema escrit "convencional".$^{3 \circ}$ Així mateix creiem que, en el nostre experiment, el context escolar ha condicionat en gran mesura una resposta de "construcció de significat", ja que hi hagué en tot moment la sensació que "havien d'interpretar". Quan acabàrem i dialogàrem informalment amb els estudiants, gairebé tots digueren: "Ens agradaria saber què volia dir l'autor". El fet d'haver estat educats "literàriament" amb aquest sistema provocà lògicament que traslladessin d'alguna manera el modus operandi de la crítica a l'aula. ${ }^{3 \mathrm{H}}$ D'altra banda, podríem afegir que gran part de les interpretacions proporcionades pels alumnes coincideixen en línies generals amb les que nosaltres hem establert a partir d'una anàlisi formal, semàntica i contextual.

Tot $i$ això, hi ha un petit espai per a la subjectivitat en el sentit de transformar el significat en alguna cosa personal, a partir de la pròpia experiència. I és en aquests casos quan podríem dir que hi ha una certa emoció derivada del significat. Pocs foren, però, els qui feren un pas més enllà i, quan ho feien, descartaven la interpretació per "inadequada". Podríem concloure, doncs, que el sentiment no hi intervingué gaire, però que s'implicaren molt a nivell personal, com es pot deduir de la lectura dels fragments inclosos en aquest article.

Un punt important a comentar és la qüestió del context en aquells poemes en què era un element decisori per a la interpretació, com ara "Record" o "Oda" de Joan Brossa. És clar que si els lectors no relacionen el full de calendari del juliol de $1936 \mathrm{amb}$ l'inici de la Guerra Civil espanyola no es pot construir un significat adequat. De tota manera, les interpretacions del poema revelaren altres significats que segurament eren a la base del joc de Brossa. En tot cas, la manca de referents contextuals és també un impediment important per a la interpretació de qualsevol poema, sigui discursiu o visual. En la mateixa línia, tot i que el poema no figurava entre els seleccionats per escriure'n algun pensament, cal dir que "Oda" de Brossa suscità cares d'estranyesa i preguntes, ${ }^{32}$ perquè desconeixien el significat del mot "oda".

És evident, com ja hem comentat abans, que els títols foren un element molt important que condicionà i aconduí les interpretacions, especialment en el poemari de Viladot. Després del buidatge de les dades, ens preguntàrem, fins i tot, què hauria passat si no haguéssim donat el títol del volum. No obstant això, les respostes al darrer poema (fig. 8) donen peu a pensar que aquí actuaren amb llibertat $\mathrm{i}$ ja no tingueren en compte per a res la pertinença a Poemes de la incomunicació. Segurament fou en aquest poema on més utilitzaren la imaginació per suplir allò que no entenien. D’alguna manera seguiren les paraules d'Eco que hem reproduït anteriorment: com més suggereix una obra més aporta el lector-intèrpret emocionalment $\mathrm{i}$ imaginativament. Potser per aquest motiu, a la pregunta final sobre si aquests poemes són adequats per a l'escola, contestaren majoritàriament que sí, tot argumentant que els nens tenen molta imaginació, aquella que ells no havien acabat de tenir pel condicionament "racional" de donar un significat.

L'experiència segurament fou massa curta i ens faltà temps per poder apro- 
fundir en la manera com els lectors no experts que havíem triat anaven donant sentit als poemes. Es tractava només d'un estudi exploratori que ens ha permès aproximar-nos mínimament al camí que segueix el lector a l'hora d'acarar-se a un poema visual. Probablement noves recerques que completin les dades amb entrevistes en profunditat, com ja s'ha comentat, aportaran més llum sobre les diferències en el procés lector entre un poema escrit "convencional” i un de visual. De moment, sabem que la "racionalitat" guanya la partida, amb un marge ampli per a la imaginació, en segons quins poemes. Continuarem, doncs, buscant les traces de la recepció de la poesia visual, amb la certesa que "la poesia visual és la recerca d'un nou terreny entre allò visual i allò semàntic” (Brossa, Anafil 206).

GLÒRIA BORDONS I DANIELA CAVALLI UNIVERSITAT DE BARCELONA

\section{REFERÈNCIES}

Arimany, Miquel. L'avantguardisme en la poesia catalana actual. Barcelona: Pòrtic, 1972.

Arnheim, Rudolf. Art and Visual Perception. A Psychology of the Creative Eye. The New Version. Berkeley, Los Angeles i Londres: U California P, I 974 .

Audí, Marc. La poésie visuelle de Joan Brossa (1919-1978): description et analyse intégrales. Tesi doctoral. Université Paris IV-La Sorbonne i Universitat de Barcelona, 20I I.

Audí, Marc, Glòria Bordons i Lis Costa. "La poesia experimental, poesia fronterera: concepte, característiques i recepció". Discurso sobre fronteras - fronteras del discurso: estudios del ámbito ibérico e iberoamericano. Ed. Alfons Gregori. Lask: Oficyna Wydawnicza LEKSEM, 2009. 383-393.

Borrès, M. Lluïsa. "Poesía visual”. Destino I724 (I 970): 39.

Brossa, Joan. Quadern de poemes. Barcelona: Ariel, I 969.

-. Poemes per a una oda. Barcelona: Ed. Montse Ester, Saltar i Parar, 1970.

—. Vivàrium. Barcelona: Edicions 62, 1972.

-. Anafil. Barcelona: Edicions 62, I987.

Bruner, Jerome. Acts of Meaning. Cambridge (Ma): Harvard UP, I990.

Burke, Michael. "Literature as parable". Cognitive Poetics in Practice. Ed. Joanna Gavins i Gerard Steen. Londres: Routledge, 2003. I I 5-I 28.

Calsamiglia, Helena, i Amparo Tusón. Las cosas del decir. Barcelona: Ariel, I999.

Cirlot, Juan Eduardo. Diccionario de símbolos. Barcelona: Labor, I982.

Crisp, Peter. "Conceptual metaphor and its expressions". Cognitive Poetics in Practice. Ed. Joanna Gavins i Gerard Steen. Londres: Routledge, 2003. 99I I I. 
Donguy, Jacques. Poésies expérimentales - Zone numérique (1953-2007). Dijon: Les presses du réel, 2007. I I-I I 9.

Eco, Umberto. Obra abierta. Barcelona: RBA, 1985 . Trad. de l'italià de Roser Berdagué. Ed. orig.: Opera aperta. Milà: Casa Editrice Valentino Bompiani, 1962.

Giralt-Miracle, Daniel. "Postal de Lérida. Exposición de poesía concreta”. Destino I743 (I97I): 35 .

Hanna, Christophe. Nos dispositifs poétiques. París: Questions théoriques, 2010.

Iglésias del Marquet, Josep. Poemas visuales. Conca: El toro de barro, i 969.

Kuiken, Don, David S. Miall i S. Sikora. "Forms of self-implication in literary reading". Poetics Today 25.2 (2004): I 7 I-203.

Lakoff, George i Mark Johnson. Metaphors We Live By. Chicago: U Chicago P, i980.

Leibovici, Frank. Des documents poétiques. París: Questions théoriques, 20 I0. Miall, David S. Literary Reading. Nova York: Peter Lang, 2006.

OTAley, Keith. "Wrtitingandreading. The future of cognitive poetics". Cognitive Poetics in Practice. Ed. Joanna Gavins i Gerard Steen. Londres: Routledge, 2003. I $62-173$.

Pont, Jaume. El corrent G. V. (L'obra poètica de Guillem Viladot). Barcelona: Promociones y Publicaciones Universitarias, I986.

Salvo, Ramon. Josep Iglésias del Marquet. Lleida: Museu Jaume Morera, 2007. Stockwell, Peter. Cognitive Poetics. Londres: Routledge, 2002.

Tannen, Deborah. "What's in a Frame? Surface Evidence for Underlying Expectations". Framing in discourse. Ed. Deborah Tannen. Nova York: Oxford U P, 1993. $14-56$.

Tsur, Reuven. "Some Cognitive Foundations of 'Cultural Programs'”. Poetics Today 23.I (2002): 63-89.

Viladot, Guillem. Poemes de la incomunicació. Agramunt: Lo Pardal, I970.

\section{Notes}

I Aquest estudi s'emmarca en el projecte d'I $+\mathrm{D}$ «La poesia experimental catalana entre I959 i 2004", referència FFI20I0-I8880 (subprograma FILO). Ha rebut també ajut de l'Agrupació de Recerca en Ciències de l'Educació de la Universitat de Barcelona.

2 D’altra banda, tota interpretació és subjectiva i no és el nostre propòsit entrar en una polèmica entre subjectivitat i objectivitat que ens portaria molt lluny de la finalitat d'aquest article.

3 Per lectors no experts entenem els que no tenen ni formació ni experiència en teoria i crítica literàries, encara que hagin tingut algun tipus d'experiència amb la literatura a l'escola.

4 Tot i que després s'ha popularitzat el terme “poesia visual” per a aquest tipus de poesia, en aquell moment la mostra portà el títol "Poesia concreta". 
s El moviment, derivat de l'art concret, nasqué d'una manera gairebé paral-lela a Alemanya i al Brasil. Max Bill i Eugen Gomringer en foren els pioners a Europa. El segon escrivia Konstellationen el 1953, mentre que l'any i952, al Brasil, Décio Pignatari i Augusto i Haroldo de Campos editaren el número i de la revista Noigandres. Entre I954 i I956, Pignatari viatjà a Europa i conegué Gomringer a Ulm. A partir d'aquest moment, podríem dir que el moviment s'estén pertot arreu amb el nom de "poesia concreta”. Per a una història completa i una antologia internacional de poesia concreta, és de referència obligada Donguy (I I- I I9). rida.

${ }^{6}$ Especialment al suplement de cultura del Diario de Barcelona i al Diario de Lé-

7 Tot i que de vegades la conversió dels poemes en serigrafies o la publicació en llibres convencionals n’esborrin el traç, tots els poemes dels tres autors són concebuts en el seu origen com a collages.

8 On s'incloïa per primera vegada la famosa "Elegia al Che".

9 Tots dos publicats a l'editorial del mateix Viladot, Lo Pardal, d'Agramunt.

Io Reproduit a <www.pocio.documenta.cat $>$. Consulta: 4-I-20I 2.

I No hem utilitzat tots els articles apareguts en aquell moment, sinó només aquells que més destacaven el paper del receptor en aquest tipus de poemes. llibre.

${ }^{12}$ Segons consta en el catàleg de la Petite Galerie, s'hi exposaren poemes d'aquest

${ }^{13}$ No indiquem el número de pàgina d'aquestes citacions perquè el llibre no està paginat.

${ }^{14}$ Alguns poemes semblen pensats per dir en veu alta. Per exemple, el poema 23 podria provocar l'efecte gairebé de poema fonètic, ja que els punts suspensius reclamen una pausa llarga i la "o" central i aillada, una pujada de volum.

Is Segons digué Viladot mateix l'any I980, "l'altre codi (el visual) serà per conèixer la pròpia neurosi, entesa aquesta, seguint el pensament de la psicòloga Marta Trepat, com una 'estructura d'al-luvió'.... El segon codi és fruit d'una inconformitat substancial davant el que podríem anomenar catàleg de significants que el sistema dominant estableix per imposar la residència en una territorialitat oficial". Text "Benefici objectual", inclòs en el programa de mà de l'exposició d'obres de Viladot, "Iconografies de l'ús i de l'oci”, Galeria Maeght de Barcelona, I 2 de febrer de I980. Citat per Jaume Pont (46).

${ }^{16}$ En Viladot és freqüent l'ús de la guia telefònica, especialment al llibre Cantates, fugues i colls de la baralla, de 1970 i publicat el I975, en què tots els poemes estan construits a partir de la guia telefònica de la província de Lleida.

${ }^{17}$ A l'hora de publicar el llibre, el poeta s'autocensurà i renuncià al poema "Oda". Això comportà el canvi del títol "Record" (el full de calendari del juliol de 36) pel d'“Oda" i la inclusió d'un nou poema, "Llibertat", pertanyent a un altre poemari, per donar un toc igualment polític però no tan contundent al final del llibre. Per aquest motiu hem utilitzat les imatges del manuscrit (Col-lecció MACBA. Centre d'Estudis i Documentació. Dipòsit Fundació Joan Brossa) i no les del llibre publicat.

I8 La seva primera obra teatral és de I944 i la totalitat de la seva poesia escènica abraça sis extensos volums.

${ }_{19}$ Agraïm al professor Joan Manuel la seva amabilitat i disponibilitat per fer possible l'experimentació a la seva aula.

${ }_{20} \mathrm{Cal}$ dir que, dels 34 alumnes, 25 coneixien Brossa ( 8 n'havien llegit algun poema i només 4 n'havien vist algun poema visual) i cap no coneixia Viladot.

${ }^{21}$ Els que aquí hem reproduit $\mathrm{i}$ interpretat.

${ }^{22}$ Per fer-ho ens hauria calgut fer entrevistes amb profunditat a alguns dels alum- 
nes, però no tinguérem prou temps ni per realitzar-les ni, després, per analitzar-ne els resultats.

${ }_{23}$ D'aquestes i de les següents respostes literals dels alumnes, només n'hem corregit l'ortografia; tot i ésser alumnes universitaris del grau de Mestre d'Educació Primària, la seva llengua és en general força deficitària.

${ }^{24}$ Ens referim als poemes amb la numeració de les figures incloses en aquest article.

${ }_{25}$ Quan parlem de metàfora, ens basem principalment en la teoria de Lakoff i Johnson i també en els plantejaments de Stockwell, Crisp i Burke, tant pel que fa a la funció metafòrica del llenguatge i del pensament com a la idea de blending i de la literatura com a paràbola.

${ }^{26}$ Atès el tipus de metodologia emprada, dissortadament no vam poder aprofundir en les respostes dels alumnes i en conseqüència no tenim dades que ens permetin saber què fa que s'activin determinats camps (personal, social, sobre l'autor...) a l'hora d'interpretar. En molts casos ni tan sols hem pogut esbrinar quins camps són els que s'activen. Contemplem el procés segons la teoria del blending (Turner i Fauconnier dins de Stockwell).

${ }^{27}$ La implicació personal, emocional i afectiva a què ens referim és, bàsicament, la que proposen Oatley, Kuiken et al. i Miall.

${ }_{28}$ Com ja hem dit, els marcadors discursius de la implicació del jo lector no sempre són evidents. Tanmateix ens hem basat en un conjunt d'elements (Calsamiglia i Tusón) per a la interpretació. La limitació de dades palesa el caràcter exploratori de la nostra recerca $i$, en conseqüència, les eventuals troballes haurien de ser objecte d'un estudi posterior, en què es fessin entrevistes qualitatives i s'utilitzessin altres eines que permetessin conèixer i interpretar els sentits reals que els participants construïen (a més de donar suport quantitatiu als percentatges esmentats). Cal tenir en compte que ens movem dins un marc qualitatiu.

${ }_{29}$ Quan parlem de marcs o esquemes interpretatius ens basem en els plantejaments de Tannen i de Stockwell.

30 Ens referim a poemes escrits "no experimentals", aquells en què es pot seguir un fil lògic de manera clara i, per tant, atorgar-los un sentit que podem relacionar fàcilment amb les nostres experiències vitals.

${ }^{31}$ Encara que els alumnes no tenen formació en estudis literaris, el seu pas per l'escola els ha mostrat aquest modus operandi que, per la influència dels estudis literaris en la didàctica, és força predominant a l'escola.

${ }^{32}$ Com que no es veia bé el text, llegírem la notícia que conté el poema i això provocà cares i expressions de sorpresa. 